\title{
LÉLEKTAN ÉS HADVISELÉS
}

Szerzők:

Mező Ferenc (PhD)

Eszterházy Károly Egyetem

Mező Katalin (PhD)

Debreceni Egyetem

Első szerző e-mail címe:

ferenc.mezo1@gmail.com

\section{Lektorok:}

Koncz István (PhD, CSc)

Professzorok az

Európai Magyarországért Egyesület

Kelemen Lajos (PhD)

Okoskocka Kft.

...és további két anonim lektor

\section{Absztrakt}

Jelen tanulmány a pszichológia, a hadtudomány és más tudományok közötti kölcsönhatásokat mutatja be. A cikk a hadviselés lélektanától a lélektani hadviselésig terjedő skálán nyújt példákat ezekre a kapcsolatokra.

Kulcsszavak: pszichológia, hadviselés

Diszciplinák: pszichológia, hadtudomány és más tudományok

\section{Abstract}

PSYCHOLOGY AND WARFARE

The Present study shows on interactions among psychology, military, and other sciences. This article provides examples of these connections in the scale from the psychology of warfare to psychological warfare.

Keywords: psychology, warfare

Discipline: psychology, military science and other sciences

Mező Ferenc és Mező Katalin (2019): Lélektan és hadviselés. Lélektan és hadviselés - interdiszciplináris folyóirat, I. évf. 2019/1. szám. 9-25. doi: 10.35404/LH.2019.1.9 
Háború és béke - nemcsak Tolsztoj klasszikus regényében, hanem a valóságban is egymáshoz kapcsolódó fogalmak, jelenségek. Áthatják és formálják életünket, történelmünket, kulturánkat, civilizációnkat (s viszont) - ergo: nem hagyható figyelmen kívül tudományos kutatásuk. Sajátos (méginkább: sajnálatos) módon azonban a tudománytörténet úgy alakult, hogy nem a béke, hanem a háború kutatása révén keletkezett egy igen összetett diszciplina: a hadtudomány. „Béketudomány" ugyanakkor nem létezik, bár a téma a hadtudományon (s a katonai gyakorlatban sajátos módon a békefenntartáshoz kapcsolódó múveleteken) belül természetesen nem ismeretlen.

\section{Interdiszciplináris megközelítés}

A háború és béke tudományos tanulmányozása azonban nemcsak a hadtudomány felől lehetséges, hanem (a téma inter- és multidiszciplináris jellege miatt) a Magyar Tudományos Akadémia 2017-ben közreadott tudományági nómenklatúrája akár minden tudományterülete felől megközelíthető (1. ábra). Csak a legnyilvánvalóbb kapcsolódási pontokra fókuszálva szerepeljen itt egy rövid áttekintés a különböző tudományterületek hadviselést érintő vonatkozásaival kapcsolatban!

Matematikai tudományok: a számtan, a mértan, a valószínűségszámítás, a kombinatórika stb. a hadviselést is szolgáló eszköz.

1. ábra: a „háború és béke” témakör multi-, interdiszciplináris jellege (forrás: a Szerzőo)

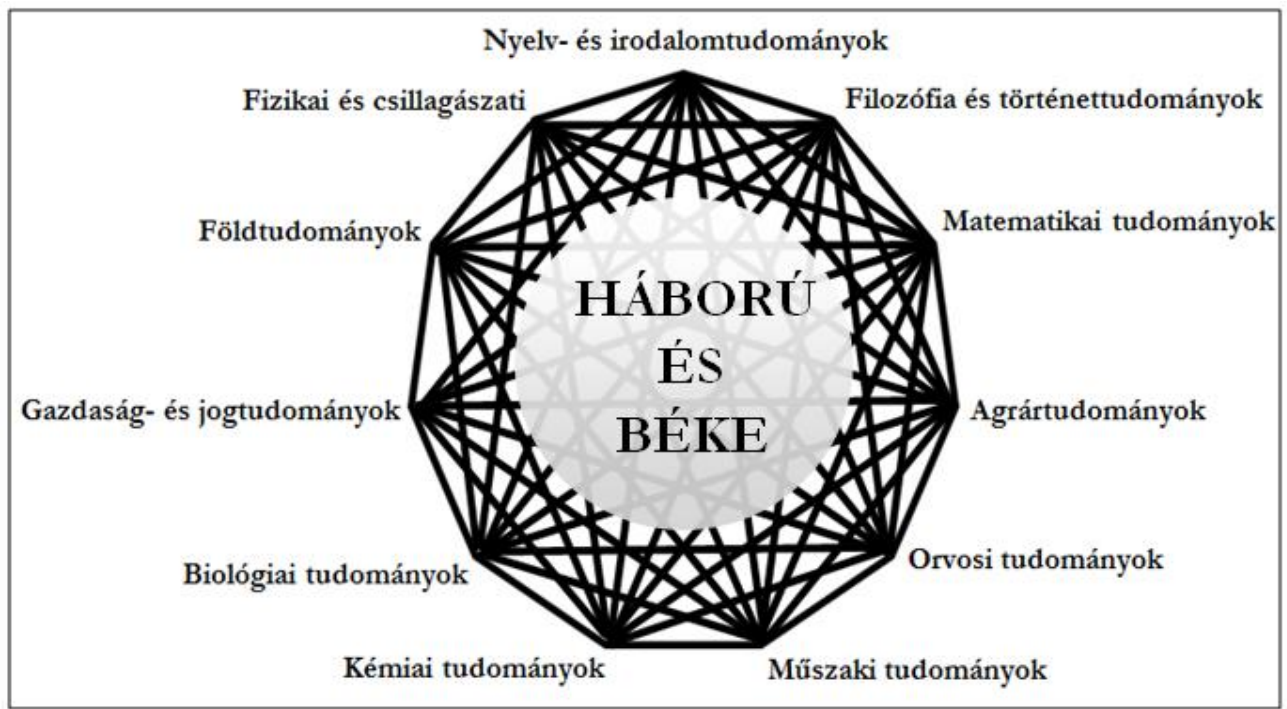


Agrártudományok: a hadseregek és/vagy a polgári lakosság élelmezése (és azon keresztül a táplálkozással kapcsolatos fiziológiai szükséglet kielégítése vagy éppen felkeltése) háborúkat váltott ki, s háborúk sorsát döntötte el a történelem során.

Orvosi tudományok: talán a legközvetlenebb asszociáció az orvostudomány és a hadviselés között a harctéri orvoslás lehet.

Müszaki tudományok: a (hadi) mérnöki teljesítmények szintén sorsdöntők egy-egy háború (vagy az atombomba és a kölcsönösen garantált megsemmisítés kontextusában: a hidegháború) szempontjából.

Kémiai tudományok: a kémiai hadviselés a legkézenfekvőbb kapcsolódási pont.

Biológiai tudományok: a biológiai hadviselés, a biológiai fegyverek fejlesztése (Lits, 2002) közvetlen kapcsolódási pontot jelent a hadviselés és a biológia között.

Gazdaság-és jogtudományok: gazdasági hadviselés, a háborús gazdaság és a hadi, illetve katonai jog területe és témakörei kötődik szorosan a hadviseléshez

Földtudományok: közismert, hogy a mindenkori terep- és időjárási viszonyok, a háborús konfliktusok föld- és vízrajzi jellegzetességei (beleértve egy-egy terület flóráját, faunáját, nyersanyag-, ásvány-bőségét vagy éppen mindezek hiányát) ősidőktől meghatározói a háborúk és békés időszakok alakulásának. Napjainkban pedig már a klímafegyverek korát éljük...

Fizilkai és csillagászati tudományok: az erősokszorozó hatású támadó és védő fegyverek fizikai alapjainak megismerésétől a csillagászati ismeretek alapján történő időmérésen és tájékozódáson át, az űrhadvi- selésig vagy éppen a hidegháborús űrversenyig terjedő skálán sok kapcsolódási pontja van e tudományterületeknek is a hadviseléshez.

Nyelv-és irodalomtudományok: a hadviseléssel kapcsolatos irodalmi művek alkotásától és azok tanulmányozásától a különböző tudományterületekben megjelenő háborús metaforákon át (jellegzetesebb példaként emlékezzünk arra, hogy a katonai terminológiában használt „stratégia” és „taktika” fogalmat előszeretettel használja példul a pszichológia - többek között „megküzdési stratégia”, „tanulási stratégia és taktika" kontextusban -, a gazdaságtudomány, a sporttudomány stb. is) a tömegkommunikációs eszközökön keresztül terjesztett - olykor neves írók által alkotott - háborús propagandáig sokféle kapcsolódás található itt is a hadviseléssel.

Az 1914-ben létrehozott brit War Propaganda Bureau (WPB, Háborús Propaganda Hivatal) egyik tevékenysége röplapok terjesztése volt, s olyan közismert és világhíressé vált írók dolgoztak itt, mint:

- Arthur Ignatius Conan Doyle (a Sherlock Holmes-történetek és Az elveszett világ írója);

- Rudyard Kipling (egyebekek között A dzsungel könyve, Riki-tikitévi és más történetek szerzője),

- Herbert George Wells (többek között Az időgép, A láthatatlan ember, Dr. Moreau szigete, a Világok harca alkotója)! 
Filozófia és történettudományok: a téma filozófiai és (had)történeti feldolgozása mellett az ebbe a tudományterületi körbe sorolt lélektani kapcsolódási pontokra fókuszálunk a tanulmány további részében.

\section{A hadviselés lélektana}

A lelki jelenségek, a hadviselés, továbbá e témaköröket kutatásuk tárgyának tekintő tudományok egymásra kölcsönösen ható kontextusban állnak egymással (lásd: 2. ábra).

2. ábra: a lelki jelenségek, a hadviselés és ezele tudományos kutatása közötti közvetlen kölcsönhatás (forrás: a Szerzōo)

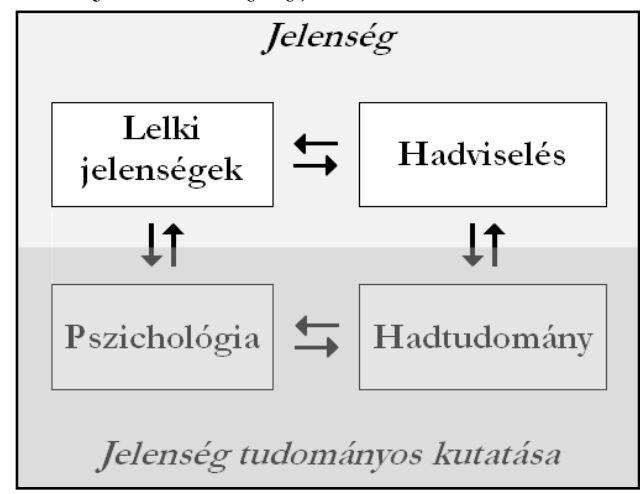

Megjegyzés: a pszichológia és a hadviselés, illetve a hadtudomány és a lelki jelenségek közötti (átlós nyílakkal szimbolizálható) kölcsönhatás jellemző módon a feltüntetett tudományterületeken keresztül, áttételesen, közvetett módon érvényesül, ezért jelen ábrán ezeket nem jelöltük

Az olyan lelki jelenségek, mint az értelmi képesség, érzelmi és hangulati jellemzők, szándékok, mindezek viselkedéses megnyilvánulásai stb., háborúban és béké- ben egyaránt befolyásolják, behatárolják a baráti vagy ellenséges közösségek, egyének sorsát, cselekvési és életben maradási, illetve boldogulási esélyeit. A lelki jelenségek meghatározó volta miatt, nyilvánvaló, hogy haszonnal járhat, ha megismerjük és érdekeinknek megfelelően befolyásolni próbáljuk azokat. Lényegében ez a pszichológiai (lélektani) kutatások általános célja.

A pszichológia tárgya szúk értelemben az ember, általánosabb értelemben pedig a pszichés jellemzőkkel bíró élőlények megismerése és az ezekkel kapcsolatos preventív, interventív módon történő hatásgyakorlás lehetőségeinek feltárása.

Meg kell jegyeznünk, hogy napjainkban már nemcsak élőlények, hanem mesterséges intelligenciák is állhatnak a lélektani kutatások fókuszában (v.ö.: Mező és Mező, 2019). A „mesterséges pszichológia” első felvetése Dan Curtis nevéhez kötődik 1963-ban (hivatkozik rá: Crowder és Friess, 2012). A témával kapcsolatban figyelemre méltó Freeland (2018) felvetése, miszerint, ha az emberéhez hasonló, ámde mesterséges intelligencia/személyiség létrehozására törekszünk, akkor az emberéhez hasonló, ámde mesterséges mentális betegségek megjelenésére is számíthatunk.

A pszichológia XIX. századi megjelenése egyrészt a lelki jelenségek (például érzékelés, észlelés, figyelem, emlékezet, gondolkodás, képzelet, érzelmek, motivá- 
ció, pszichés betegségek stb.) iránti fokozott érdeklődésnek, másrészt a lelki jelenségekkel kapcsolatos megfigyelések és elméletek mérésére, bizonyítására való törekvésnek köszönhető.

A pszichológián belül a XX. századra megtörtént a lelki jelenségek körül-írtabb területei alapján történő differenciálódás, $\mathrm{s}$ az általános lélektan mellett kialakult például a személyiség-, a fejlődéslélektan, valamint a szociálpszichológia. Ezek mellett az elméleti, alapkutatás jellegú pszichológiai területek mellett az alkalmazott pszichológiai megközelítések is kialakultak: ezek lényegében a lélektani ismeretek gyakorlati felhasználására vállalkoznak egy-egy szűkebb probléma-, vagy feladatkör elemzése, és az azokkal kapcsolatos események befolyásolása révén. Vegyük észre, hogy az alkalmazott pszichológia révén nemcsak a lelki jelenségeknek van (végsősoron) pszichológia tudományt megalapozó hatása, hanem a pszichológia is hosszabb-rövidebb, egyéni vagy csoportszintủ hatást gyakorolhat lelki jelenségekre. Jellegzetes alkalmazott pszichológiai területek többek között: a klinikai lélektan, a munka- és szervezetpszichológia, a pedagógiai pszichológia, a közlekedéslélektan, a környezetpszichológia, a sportpszichológia, a reklám-pszichológia, vagy akár: a katonapszichológia!

\section{Katonapszichológia}

A katonapszichológiát tekinthetjük a hadviseléshez és a hadtudományhoz legközvetlenebb módon kapcsolódó alkalmazott pszichológiának (Pavlina és Komar,
2007). Az alkalmasságvizsgálatokon túl napjainkban a katonapszichológusok (csapatpszichológusok) feladata kiterjed a katonai szolgálattal járó - a civil élettől jelentősen eltérő - kötelmi, fegyelmi elvárásokhoz, valamint fizikai és/vagy érzelmi terheléshez történő alkalmazkodás segítésére. Gondoljunk egy másik ember megölésével járó, vagy éppen a szolgálatot teljesítő bajtársak halálával kapcsolatos trauma feldolgozására, s az akár öngyilkosság végkimenettel járó poszttarumás stressz szindróma felismerésére, kezelésére. Ezen kívül a katonapszichológusok szerepet vállalhatnak a külszolgálatra készülő állomány felkészítésében, missziós területeken történő támogatásában (például interkulturális-sokk, honvágy, otthoni szerettekért való aggódás, fizikai környezet, fenyegettség, frusztráció stb. preventív/interventív kezelése tekintetében) és a hazaérkezést követő visszailleszkedés segítésében is.

Sajátos módon azonban nemcsak a hadtudomány építkezik a pszichológia elméleti és gyakorlati repertoárjából, hanem létrejötte során a pszcichológiai tudás és módszertani repertoár alakulásába a hadtudomány, hadviselés is szerepet játszott. Ennek demonstrálására követekezzen itt néhány példa a pszichológia jellegzetes területeinek katonai vonatkozásairól (a teljesség igénye nélkül).

\section{Az intelligenciakutatás hadviseléssel kapcsolatos aspektusai \\ $\mathrm{Az}$ intelligencia tesztelésének (mint az egyik közismert és jellegzetes pszicholó-}


giai kutatási témának a) kezdete szoros kapcsolatban áll a hadviseléssel is.

Az Egyesült Államokban az I. világháborúba történő csatlakozás kapcsán merült fel az igény arra, hogy a katonai toborzás, sorozás alkalmával ki lehessen szűrni az értelmi képességeik alapján katonai szolgálatra alkalmatlan személyeket. Ehhez olyan intelligenciatesztek létrehozására volt szükség, amelyek az angolul tudó, illetve az írástudatlan vagy angolul nem tudó vizsgálati személyekkel is felvehetők. Az USA kormánya az Amerikai Pszichológiai Társaság akkori elnökét, Yerkes-t és munkatársait bízta meg e tesztek kidolgozásával. Ennek eredményeként jöttek létre az Army Alpha (verbális) és az Army Beta (nem várbilis) intelligenciatesztek. Ebben az időszakban mintegy 2.000.000 (!) katonai szolgálatra jelentkező személy vizsgálata történt meg (Rózsa és Hevesi, 2006).

A katonai oldalról felmerült igény tehát pszichológiai kutatásokat ösztönzött, s ennek eredményei később civil felhasználásra kerültek a klinikai, a munka- és szervezet, valamint a pedagógiai-pszichológia terén.

Mindezen kívül az intelligencia mérésének szomorú történeti aspektusa, hogy alacsony intelligenciájúnak tekintett személyek kényszersterilizációjával, és a náci felsőbbrendű ember eszméjéhez kötődő II. világháborús népírtással is kapcsolatba hozható (noha nem ez volt a tesztalkotók szándéka).

A világ első objektív intelligenciavizsgáló eljárását a XIX-XX. század forduló- ján Sir Francis Galton dolgozta ki - többek között eugenikai tárgyú kutatásaihoz.

A Galton-féle eugenika (a „jó öröklés tudománya”) tulajdonképpen egy embertenyésztési program, melynek lényege: miként a mesterséges szelekció révén növényeket és állatokat tud speciális (örökölhető) tulajdonságok mentén nemesíteni az ember, úgy akár az emberi faj is nemesíthető lehet.

Mivel az embert az állatvilágból az intelligencia emeli ki, kézenfekvőnek tűnhetett, hogy az emberiséget az intelligencia alapján szükséges tenyészteni. Ezt egyrészt a pozitív eugenika (intelligens emberek gyermekvállalásának facilitálása) révén képzelték el, másrészt a negatív eugenika (a kevésbé intelligens emberek gyermekvállalásának korlátozásával, tiltásával, lehetelenné tételével) kívánták elérni. A cél érdekében Európában és az USA-ban egyetemi tanszékek, kutató intézetek szerveződtek, s az USA-ban például alacsony intelligenciához kötött kényszersterilizációs, illetve bevándorlási törvények is születtek.

A történet már így is eléggé megrázó, de ha belegondolunk, hogy a náci felsőbbrendû ember eszményébe is jól beágyazható lehetett az eugenika (s vele az intelligenciakutatás), akkor már egészen hátborzongatóvá válik, hogy egy máskülönben hétköznapi kutatási téma (az, hogy miként mérhető az intelligencia), milyen borzasztó következményekkel járhat, vagy milyen célokat szolgálhat, ha valaki nem a béke, hanem a háború eszközének tekinti. A cél nem szentesíti az eszközt. 


\section{A tehetség tudományos kutatásának}

\section{hadviselést érintö vonatkozásai}

A tehetséggondozás kutatásának is sajátos kapcsolódási pontjai vannak a háború, hadviselés, hadtudomány témakörrel. A már említett Army Alpha és Army Beta névre hallgató intelligenciatesztek alkalmazásában is részt vett Terman a XX. század első felének meghatározó alakja volt a tehetségkutatás terén is (Mező K., 2012). A katonai alkalmazás terén szerzett tesztelési tapasztalatokat pedagógiai célú, gyerekek körében végzett vizsgálatokra is alkalmazta. Ennek lett egyik eredménye a nevéhez füződő (napjainkban ugyan már túlhaladott, de még mindig sokat idézett, s nagy hatású) Terman-féle tehetségkoncepció, miszerint a tehetség nem más, mint kimagasló intelligencia (Terman, 1925).

A pszichológia és a háború találkozásának másik történeti szála a tehetség-kutatással kapcsolatban a szovjet Szputnyik1. múhold 1957-es fellövéséhez kötődik, és a tehetségkutatás történetében Szputnyik-sokként emlegetett jelenséghez kapcsolódik. Ennek lényege: a II. világháborút követő hidegháborús időszakban az USA és a Szovjetunió gazdasági, ideológiai és tudományos versenyben állt egymással. E korabeli két nagyhatalom már atombombával is rendelkezett, s jóformán csak a MAD (Mutural Assured Destruction, magyarul: kölcsönösen garantált megsemmisítés), az elrettentés politikája tartotta vissza a feleket az atomháború kirobbanásától (Szabó, 1995). Ebben a pattanásig feszült helyzetben az egész világot - különösen az USA-t - sokkolta a hír: 1957. október 4-éről 5-re virradó éjszakán a világon elsőként a Szovjetunió bocsátott fel mesterséges égitestet, a Szputnyik-1. műholdat. Mindenki számára nyilvánvaló volt - többek között a korbeli sajtó hatására -, hogy egy potenciális harmadik világháborút az nyerhet meg, aki uralja a világürt, és a Naprendszert az „gyarmatosíthatja”, erőforrásait az hasznosíthatja, aki űreszközzel rendelkezik.

A Szputnyik-sokk hatására egyrészt 1958-ban létrejött az USA űrkutatásban napjainkban is jelentős szerepet játszó és közismert Nemzeti Repülési és Ürhajózási Hivatal (National Aeronautics and Space Administration, NASA). Másrészt kvázi nemzetvédelmi oktatási törvényt vezettek be, melynek missziója lényegében az volt, hogy a szovjet tudománnyal versenyképes fiatalok nevelésére kell törekedni az USA-beli iskolákban - ennek eszköze pedig: a tehetséggondozás! Harmadrészt az USA-ban az 1950-es éveket a (tehetségkomponensnek is tekintett) kreativitáskutatás (Mező K, 2012), az 1960-as éveket pedig a „Nagy Tehetségvadászat” évtizedének tekinthetjük.

Láthatjuk, hogy a (hideg)háború ebben az esetben is motivációt jelentett bizonyos pszichológiai témák kutatásához, amelyek eredményeit aztán a katonain kívül (olykor: mellett vagy helyett) békésebb, polgári felhasználásra is hasznosította a társadalom.

Napjainkban Magyarországnak is van Nemzeti Tehetség Programja (lásd: 126/2008 Országgyűlési Határozat), és a 
tehetségazonosítás az iskolai gyakorlaton túl, a pályaorientáció, valamint a munkaerő kiválasztás terén is alkalmazható gyakorlat.

\section{Stressz- és neurózis kutatások kapcsolata a hadviseléssel}

A szorongásos panaszok kezelése szintén közismert pszichológiai téma. E terület kutatásának nemcsak civil, hanem katonai jellegű gyökerei is vannak. Nem véletlenül: a distresszt okozó harctéri élményeknek kitett katonák pszichikuma elkerülhetetlen módon reagál az extrém fizikai és lelki megpróbáltatásokra - próbál megküzdeni azokkal. A megküzdés azonban olykor kevésbé sikeres, és rövidebb- hosszabb ideig megjelenő (akár a traumát követően éveken át elhúzódó) szorongásos tüneteket okozhat. A poszttraumás stressz (post-traumatic stress disorder, PTSD) kutatásának gyökerei kifejezetten a „gránátsokk” vagy „harctéri fáradtság” jelenségéig nyúlnak vissza (Spiller, 1989).

Az Orosz-Japán háború (1904-1905) során ismerik el elsőként hivatalosan a harci stressz hatásaira bekövetkező veszteségeket. Akadtak ugyanis olyan katonák, akiken noha nem volt külső sérülés, mentálisan mégis olyan állapotba kerültek, hogy nem szolgálhattak tovább katonaként. Például: 1904 végén Harbin (kínai) városba települt orosz pszichiátriai kórházban 1700 ilyen tünettel rendelkező személyt kezeltek.

\section{1. kép: lövészárok (forrás: bttps:/ / pixabay.com)}

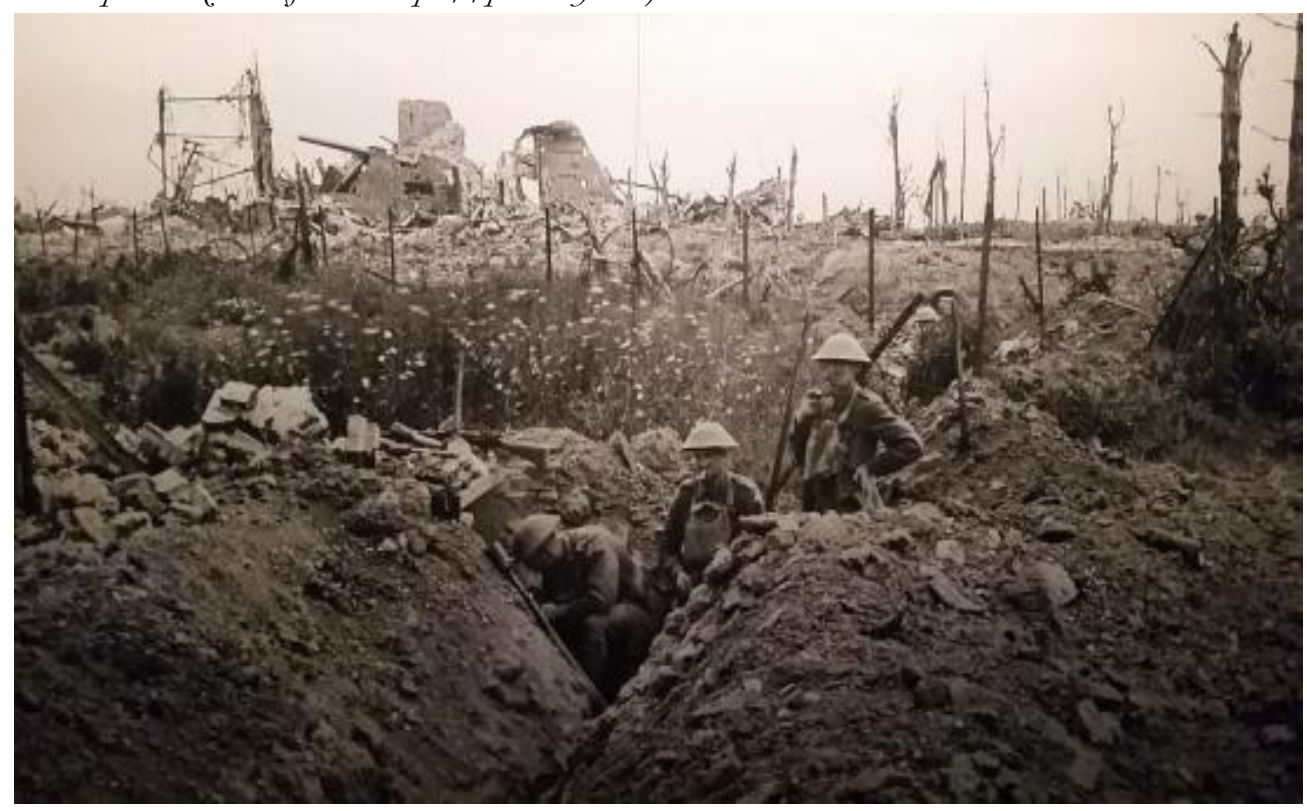


Az első világháború során „gránátsokkos"-nak nevezett betegek ezreivel kellett a nyugati fronton küzdő seregeknek szembesülniük. A nagyságrendek érzékeltetése végett: a brit hadsereg összes veszteségének 4\%-át, 41746 főt érintő pszichiátriai jellegű veszteséget jelentett 19161920 között. Az amerikai veteránok kórházában pedig 1924-ben az összes páciens 58\%-a (tehát több, mint a fele!) volt gránátsokkos: 68000 pácienst gondoztak ilyen problémával.

A második világháborúban „harci fáradtság” lett a gránátsokk újabb elnevezése. A tengeren túli hadszínterekről 1944ben a harci fáradtság miatt kellett visszahozni a legtöbb katonát. A pszichiátriai okok miatt a katonai szolgálat alóli felmentést kapó emberek száma meghaladta az egymillió főt (Spiller, 1989). A szolgálat alól felmentést nem kapók számáról nincs adat, de feltételezhető, hogy a nem diagnosztizált esetek már ekkor is a többszörösét jelenthették az iménti értéknek. A „harci fáradtság” kíméletlenül szedte tehát az áldozatait a második világháború folyamán is - rangra, életkorra, nemzetiségre való különösebb tekintett nélkül.

A vietnámi háború során ismét új nevet kapott a tünetegyüttes: ekkor került bevezetésre a ma is használt (a katonai „gránát”, „harctéri” szavaknak sokkal általánosabb, civil helyzetre is alkalmazható) poszttraumás stressz-szindróma (sérülés, megrázkódtatás utáni stressz-tünetegyüttes, ismert még: post-traumatic stress disorder, PTSD megnevezése is). A viet- námi háborúban részt vettek $80 \%$-a szenvedett ilyen sérüléstől (Spiller, 1989).

A háború során kialakuló, elhúzódó, a katonákat tartós distressz hatása alá kényszerítő harcok némely katona esetében tehát sajátos tüneteket eredményezett (egymást nem kizáró módon, de egymást törvényszerűen sem feltételező módon): harci helyzetben leblokkoltak, kiszolgáltatottakká és dezorientálttá váltak, alvásproblémáik alakultak ki, öngyilkosok lettek, esetleg saját társaik ellen fordultak. Mindez természetesen egyéni emberi szempontból is szörnyü, de a katonák harcértékének csökkenése a csata/háború szempontjából egyenesen katasztrofális következményekkel járó tünetegyüttes lehet.

Az adott helyzetben átélt distressz azonban még nagyobb rombolást képes végrehajtani az emberi pszichében: jóval az adott traumát követően is szorongásos jellegü, stressz-tüneteket produkálhat. A PTSD nemcsak katonákat súlythat, hanem a polgári lakosságra irányuló terrortámadások túlélőit, szem- és fültanúit (Galaskó, 2002), sőt: hétköznapi életben (értsd: nem háborús körülmények és nem terrortámadások során) megélt traumák (például balesetek, bűncselekmények stb.) áldozatait és közeli hozzátartozók halálát megélőket is. Egy hirtelen bekövetkező súlyos katasztrófát követően a túlélő lakosság (Pauchard, 1989):

- kb. 20\%-a ôrzi meg a lélekjelenlétét és válik viszonylag cselekvőképessé.

- 75-80\%-a pánikszerú félelembe esik 
és ellenőrizhetetlen érzelmekkel reagál. A többség néhány perctől órákig terjedő idő alatt magához tér.

- 2-3\%-ánál olyan erôs pszichikai tünetek jelentkeznek, hogy közvetlen orvosi beavatkozásra lesz szükség.

Ugyanakkor az érintettek több, mint 50\%-a esetében várható, hogy bár cselekvőképes marad, mégis akár évekig is elhúzódó pszichikai károsodást szenved.

\section{Az attitüd-és kommunikáció-kutatás}

\section{hadviseléssel kapcsolatos alapjai}

Az attitűd(módosítás), a meggyőző közlés, a manipuláció, a tömegkommunikáció kutatásának is vannak háborús gyökerei. A II. világháború tapasztalata rámutatott a náci propagandagépezet félelmetes hatékonyságára: viszonylag kisszámú csoport hatalmas tömeget tudott fanatizálni, s végsősoron Hitler hatása alá vonni. A témát tanulmányozó korabeli szociál-pszichológusok „Németországot egy tömeges attitűdmódosítás termékének tartották - azaz egy masszív kognitív változásénak -, melyet a hihetetlenül hatékony propaganda eszközeivel értek el" (Zajonc, 1984, 556. o.). A háborút követően a Yale Egyetemen indultak be a fasiszta propaganda elleni harc céljából az attitűdváltozás és kommunikáció tárgyú kutatások. A Yale-program eredményeivel kapcsolatban lásd például Hovland, Janis és Kelley (1953), Hovland (1954), Hovland és Rosenberg (1960), Sherif és Hovland (1961) műveit. A háborús tapasztalatból kiinduló pszichológiai kutatások eredményei a civil életben is felhasználásra ke- rültek. A reklámpszichológia vagy éppen a pedagógiai pszichológia többek között arról is szól, hogy miként lehet a poteciális vásárlók, illetve a diákok attitűdjét adott termékek, márkák, szolgáltatások igénybevétele, illetve a tanulás, egyes tantárgyak, témakörök, nevelési célok felé fordítani. Az attitűdök alakítására vonatkozó lehetôségek kutatása/alkalmazása a lélektani hadviselésnek is kiemelt témája.

\section{Lélektani hadviselés}

A hadviselés és a pszichológia interakciójának speciális metszetét képezi a lélektani hadviselés területe. A pszichológiai hadviselés erősokszorozó hatású, nem halálos fegyver, ami háborúban és békefenntartó múveletekben egyaránt alkalmazható.

„Nem az az igazán ügyes, aki száz csatában győzni tud, hanem az, aki harc nélkül vesz erőt az ellenségen!”

Sun $\mathrm{Cu}$

(i.e. IV. század)

Lényegében az állatvilágban is ismert a ragadozók, prédaállatok vagy fajtársak elleni küzdelemben ismert álcázó, méretnövelő, színváltoztató, hanghatásokkal operáló stb. hatáskeltés. Az emberi értelem és nyelv megjelenése maximalizálta e lelki hatáskeltésben rejlő lehetőségeket. Másként: az egymás érzelmi, értelmi befolyásolásán alapuló lélektani erősokszorozó 
hatásra törekvés - egyfajta laikus lélektani hadviselés - az emberré válás hajnala óta adott.

A pszichológiai hadviselés történeti alakulását azóta is meghatározza a kommunikációs lehetőségek és eszközök fejlődése. Történetisége ugyanakkor megragadható a terminológiai változásokon és a pszichológiai hadviselésre szakosodott orgánumokon keresztül is (3. ábra).

Amint a 3. ábrán látható, a lélektani hadviselési célra alkalmazható kommunikációs lehetőségek fejlődési íve a nonver- bális kommunikációtól kezdve a beszéden, íráson, nyomtatáson, fényképezésen, hangrögzítésen, mozgófilmen, rádión és televízión át napjainkban az internetig tart.

A 3. ábrának a lélektani hadviselés szempontjából történetileg jelentős szervezetek kialakulását jelző II. része a teljesség igénye nélkül mutatja, hogy minden jelentős nagyhatalom elkezdett ilyen jellegú szervezeteket létrehozni az első világháborútól kezdődően. Napjainkban például a NATO-doktrínának is van lélek-

3. ábra: a pszichológiai hadviselés történeti aspektusai (Mező, 2014, 22. o.)

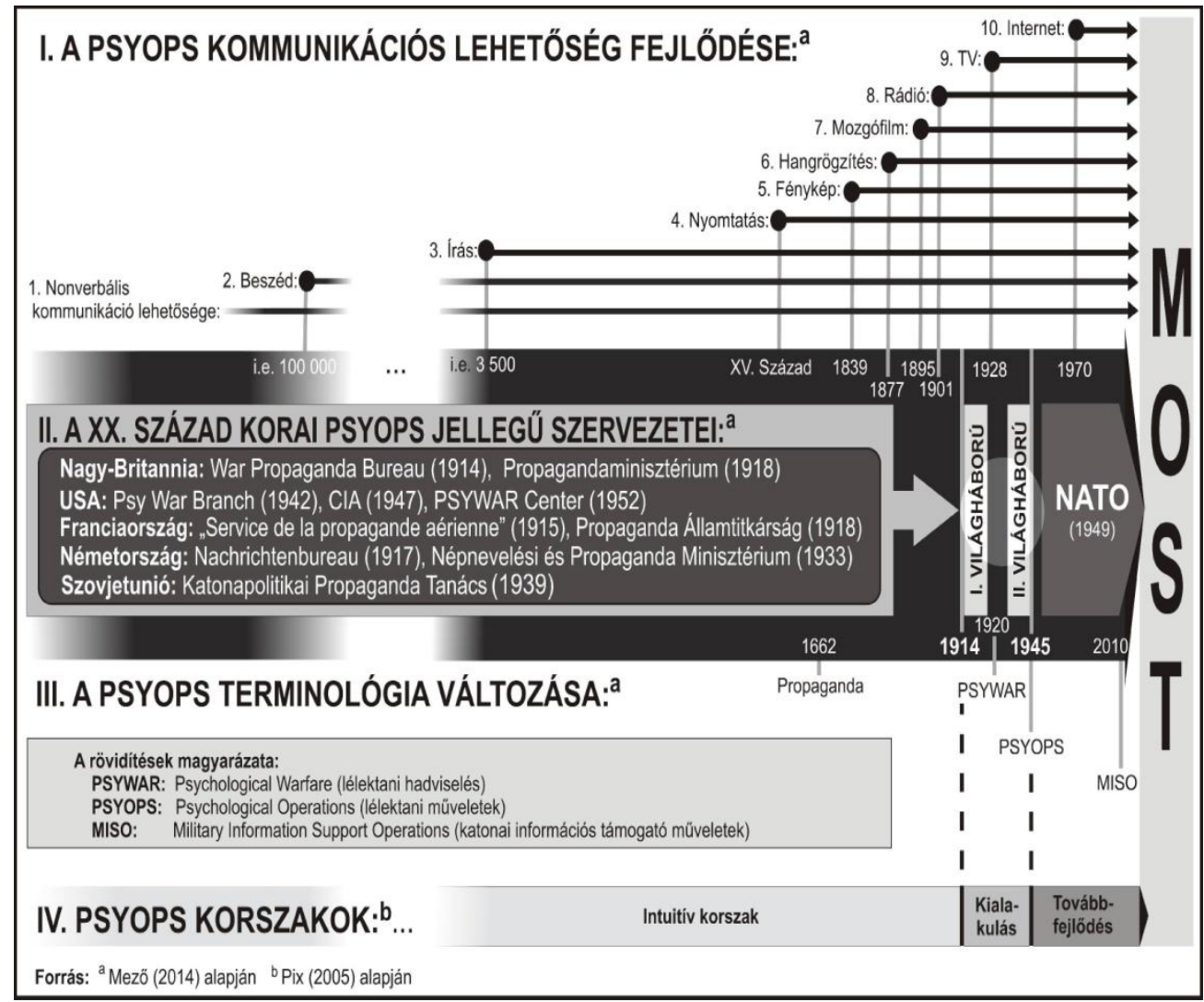


tani hadviselés jellegü része - PSYOPS (psychological operations, lélektani múveletek) név alatt (lásd: AJP-3.7, és AJP3.10.1).

A 3. ábra III. sávja a terminológiabeli változásokat foglalja össze. A „psychological warfare” (rövidítve: PSYWAR, magyarul: lélektani hadviselés) kifejezést J.C. Fuller 1920-ban alkalmazta először angolul (Daugherty, 1982). A kifejezés azonban csak 1941-tôl vált közismertté egy náci propagandával kapcsolatos szöveg révén (Farago és Gittler, 1942).

A lélektani hadviselés (Szabó, 1995, 813. o. alapján)...

...angolul: psychological warfare, ...franciául: guerre psychologique ...olaszul: operazione psicologica ...oroszul: психологическая война ...németül: die psychologische

Kriegsführung

Végül, a 3. ábra IV. sávja Pix (2005) lélektani hadviseléssel kapcsolatban javasolt korszakolását mutatja be.

Az alábbiakban történelmi példákon keresztül demonstráljuk a lélektani hadviselés gyakorlati megoldásait.

\section{Humán szü̈ségletekre \\ irányuló lélektani hadviselés}

A szükségletek felkeltésére, kielégítésére, kielégítésük vagy felkeltődésük megakadályozására irányuló műveletek célja, hogy a célközönséget olyan lelki és/vagy fizikai állapotba hozza, ami a lélektani hadviselést alkalmazó fél számára előnyt jelent.

Maslow (1988) szükséglet hierarchiamodellje kellően tagolt, s általános érvényű ahhoz, hogy a NATO lélektani múveletekről szóló AJP-3.7-es doktrinája is felhasználja (Bolgár, 2005). A szükséglet hierarchia eredeti elmélete szerint öt szükséglet létezik (ezek: fiziológiai szükséglet, biztonság iránti igény, szociális szükséglet, önbecsülés és tisztelet iránti igény, önmegvalósítás szükséglete), melyek aláfölérendeltségi viszonyban vannak egymással. Egy magasabb rendű szükséglet csak akkor kezdi a viselkedést befolyásolni, ha az alacsonyabb szintű szükségletek legalább részben ki vannak elégítve.

Szerepeljen itt egy tömör hadtörténeti példatár a szükségletekkel operáló lélektani hadviseléssel kapcsolatban (vö. 4. ábra)! Megjegyzés: az alábbiakban olvasható lélektani hadviselési alkalmazás már nem Maslow-tól származik, de az általa felvetett alapokon nyugszik.

A szükségletekkel operáló lélektani hadviselés vagy a szükségletek aktiválását (felkeltését, illetve kielégülésük megakadályozását), vagy pedig azok deaktiválását (felkeltődésük megakadályozását, illetve kielégítésüket) célozhatják (Mező, 2014).

A firiológiai sæülkségletek esetében például már az ókortól ismert háborús, illetve ostrom stratégia az ellenség testi-lelki erejének megtörése kiéheztetés és/vagy folyadékmegvonás révén. Klasszikus példa: Alesia ostroma során Julius Ceasar kiéheztette Vercingetorix (gall törzsfö) sere- 
4. ábra: példák a sqükeségletekekel operáló lélektani hadviselésre a Maslow-féle sqü̈.séglethierarchia elmélet kapcsán (forrás: a S zerző́k).

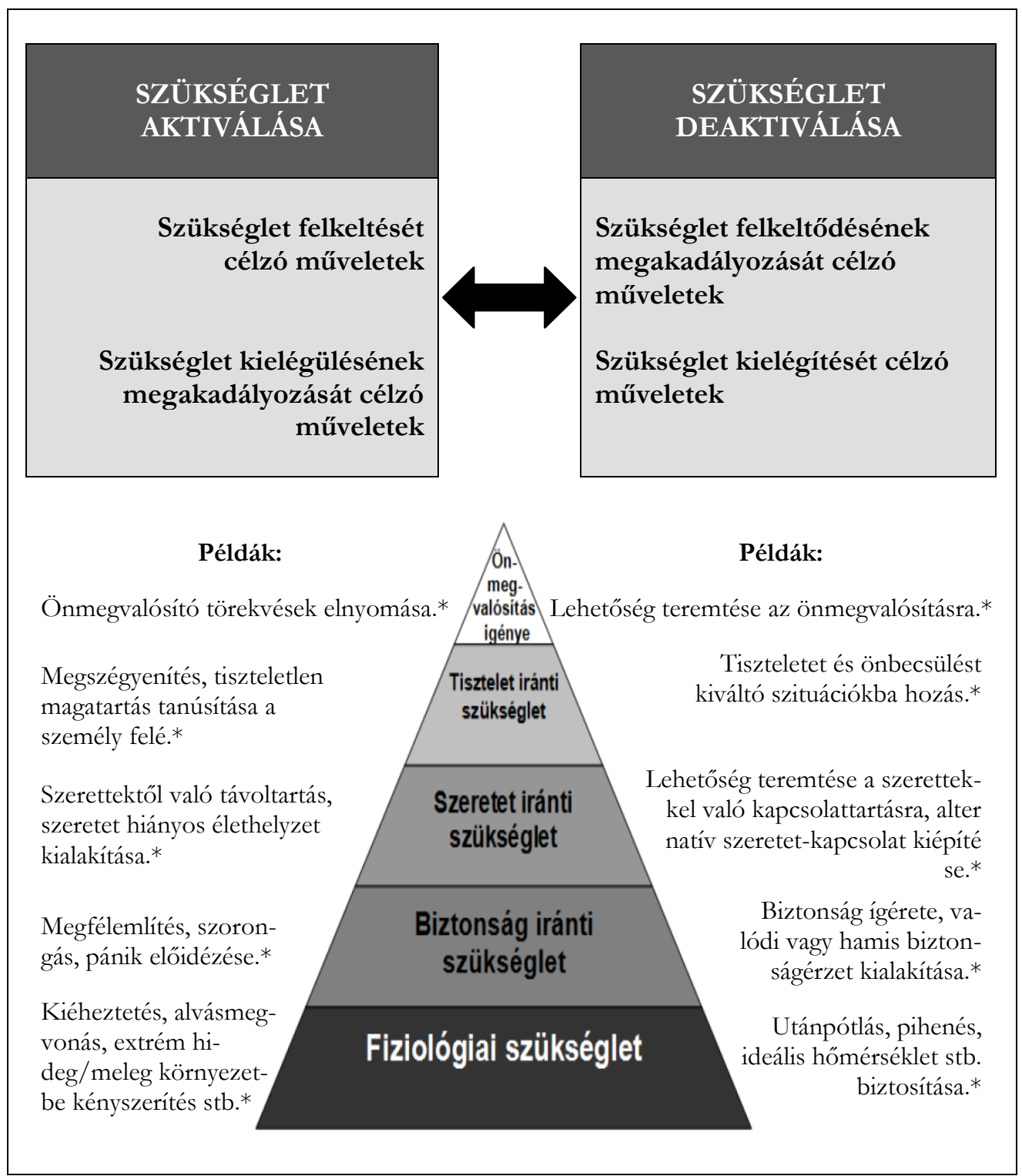

* Valamint: az ezekről szóló (ál)hírek terjesztése.

Megjegyzés: Maslow elméletének nem része a szükséglet aktiválása/deaktiválása, $\mathrm{s}$ ezek lélektani hadviselésre történő alkalmazása 
gét, mire az megadta magát (Warry, 1980). Mint Holmes (1997, 20. o.) megjegyzi: „A logisztika a hadsereg mozgatásának és ellátásának gyakorlati tudománya. Sok igazság van ebben a mondásban: »Míg az amatőr harcászatról beszél, a profi ellátásról.« Az I. világháborúig egy hadsereg működésének legfőbb feltétele a katonák és lovak élelmezése volt."

Egy másik, a lélektani hadviselés szempontjából jelentős „hadtörténeti múlttal” rendelkező fiziológiai szükséglet az alvás iránti igény. Az alvásmegvonás, a pihenés megakadályozása, stressz tüneteket produkál, s rontja a harci morált és teljesítményt (vö.: Bolgár, Hajdú és Szternák, 2008 alapján). Példa: a vietnámi háborúban az amerikaiak alacsony magasságú repülő ,áthúzásokkal”, túlhangosított rádióadásokkal, éjszakai helikopteres repülésekkel, hangszórókon keresztül a családról és a holt bajtársak lelkéről közvetített üzenetekkel akadályozták a vietkon harcosok pihenését, demoralizálták őket, aminek hatására harcértékük csökkent, a szökések száma pedig lényegesen megnőtt (Knezović és Milković, 2007).

A fiziológiai szükségletek fogalmába nagyszámú egyéb, alapvetően biológiai alapokon nyugvó szükséglet is beletartozik (plédául: szex iránti igény, komfortérzést okozó hőmérséklet iránti igény stb.), melyek részletezésétől itt eltekintünk.

Biztonság iránti igény lélektani hadviselésbeli alkalmazásának egy kiragadott hadtörténeti példája: 1940-ben a németek francia nyelvű rádióprogram sugárzásával akkora pánikot okoztak Franciaország inváziója során, hogy a menekülő lakosság káoszt idézett elő az utakon, s ezzel a Szövetségesek múveleteit jelentősen hátráltatta. Dupuy és tsai (1993) szerint ez az akció tekinthető a német rádiós propaganda legsikeresebb múveletének.

A sqociális szükeségletre is fókuszálhat a lélektani hadviselés. Szerepeljen itt ezzel kapcsolatban két történelmi példa. Az első azt mutatja meg, hogy kr.e. 380 körül a thébai „szent csapat” esetében Gorgidasz a szociális szükséglet kielégítését a saját csapatnál rendhagyó módon oldotta meg: a 300 fős elit egység homoszexuális szerelmespárokból állt. Mint Warry (1980, 64. o.) kommentálja az esetet: „Egy szerelmespár mindkét tagja ihletet meríthet a másik jelenlétéből, ami fokozhatja elszántságát, és megakadályozhatja, hogy szégyenben maradjon a csatamezőn". A másik példa a szociális szükséglet felkeltésével történő dezertálásra késztető röplapot mutat be. E röplapot a II. világháború során az US Navy csendes óceáni flottájának lélektani hadviselésre szakosodott egysége (CINCPAC) állította elő (kódszám: 411, méret: 5 x 8 inch), hogy az ellenség soraiban a családdal kapcsolatos aggodalmat ébresszen (Friedman, 2005) a szöveg:

„Miközben folytatjátok reménytelen ellenállásotokat a mi mindent elsöprő erőnk ellen, feleségeitek, nővéreitek és lányaitok a hátországban naponta prostitúcióra kényszerülnek. Nehéz idők járnak a gazdáitokra, és nagy szükség van pénzre, ami köny- 


\begin{abstract}
nyen szerezhető, ha a nőket a bordélyházaknak adják el. A gyári munkások, akiknek most van pénzük, mindig buzgón fizetnek egy-két yent a nőkkel történő éjszakai mulatságért. Amikor eljön hamarosan a béke, egy ideig otthon még rosszabb lesz. Ez minden országban így lesz. Kivéve, ha otthon vagytok és gondoskodtok a családotokról, a számotokra legkedvesebb nőkről, akik különben arra kényszerülnek, hogy prostituáltakká váljanak. Képesek vagytok érzelem nélkül gondolni asszonyaitokra, lányaitokra és nővéreitekre, akiket alávetettetek a gúnyolódó munkások kéjvágyó ölelésének? Ne dobjátok el az életeteket hiábavalóan! A családjaitoknak szüksége van rátok!"
\end{abstract}

Az önbecsülés és a tisztelet iránti igény is „célpont” lehet a lélektani haviselés szempontjából. Vonatkozó hadtörténeti példák: i.e. V. századból ismertek az ellenség provokálására, kigúnyolására (is) alkalmas feliratokkal ellátott 25-30 grammos paritytyalövedék (Warry, 1980); a saját oldalt a szóban forgó szükségleten keresztül motiváló, a hőssé vagy hősi halottá válást elismerő kitüntetések.

Végül, az önmegvalósitás iránti igényre is építhet a lélektani hadviselés. Példa: 1780tól II. József utasítására a katonatoborzás érdekében Verbunk Kommandók (toborzó parancsnokságok) alakultak (Pécsi, 1989), amelyek a hadkiegészítés érdekében a katonaéletet, mint az önmegvalósítás egy lehetséges eszközét kínálták Magyarországon is. Az önmegvalósítás iránti igényre épül a dezertált és átálló személyeknek ígért karrierlehetőség is.

Az emberi szükségleteken kívül más pszichológiai jelenségekre is reflektálhat a lélektani hadviselés - köztük a már említett attitűdökre is - ezek kifejetése azonban jelen tanulmányak nem célja. A téma iránt érdeklődők figyelmébe ajánljuk Mező (2014) „PSYOPS - avagy: kalandozás a hadak útján, a pszichológia ösvényein, a történelem útvesztőiben" című művét.

\section{Zárógondolatok}

A hadviselés lélektanától a lélektani hadviselésig terjedő spektrumban sokféle kapcsolódási pontot találhatunk a pszichológia és a hadtudomány között. A „háború és béke" témaköre azonban nemcsak e két tudományág szempontjából lehet alapvagy alkalmazott kutatás tárgya, hanem jóformán miden tudományág reflektálhat a témára - e tanulmány elején erre is igyekeztünk rámutatni. Mégis, a nagyszámú lehetséges tudományterület közül a lélektan és a hadviselés kapcsolatának részletesebb kifejtését e tanulmányban az Egyesült Nemzetek Tudományos, Oktatási és Kulturális Szervezetének alkotmánya (az UNESCO alkotmányt lásd: 1948. évi XL. törvény, valamint: 2009. évi XXXII. törvény) alábbi sorai ihlették:

„Minthogy a háborúk az emberi elmében kezdődnek az emberi elmében kell kiépítenünk a béke védelmét is..." 
Az UNESCO alkotmány idézett természetesen nem a lélektani hadviselésről szól, a citált tartalom azonban interpretálható e speciális hadviselés esetében is.

\section{Irodalom}

126/2008. (XII. 4.) OGY határozat a Nemzeti Tehetség Program elfogadásáról, a Nemzeti Tehetség Program finanszírozásának elveiröl, valamint a Nemzeti Tehetségügyi Koordinációs Fórum létrehozásának és müködésének elveiröl

AJP-3.7 - Nato Psychological Operations

Doctrine (2002)

AJP-3.10.1 - Allied Joint Doctrine For Psychological Operations (2007)

Az UNESCO Alkotmánya, 1948. évi XL. törvény. In: http://www.unesco.hu/ index.php?type $=$ node\&id $=801 \quad$ (A magyar UNESCO Bizottság hivatalos honlapja). Letöltés: 2008.07.24.

Az. UNESCO Alkotmánya, 2009. évi XXXII. törvény In: http://www. unesco.hu/unesco-www-unesco-org/ alkotmany/unescoalkotmanya (A magyar UNESCO Bizottság hivatalos honlapja). Letöltés: 2014.01.30.

Bolgár J. (2005): A lélektani műveletek pszichológiai alapjai. Humán Szemle, XXI. évf. 2005/2.; 74-80. pp.

Bolgár J., Hajdú I. és Szternák Gy. (2008): A katonai müveletek háttere, megvivásuk.jellemzôi napjainkban. Zrínyi Miklós Nemzetvédelmi Egyetem, Kossuth Lajos Hadtudományi Kar, Szárazföldi Műveleti Tanszék, Budapest.
Crowder, J. A. \& Friess, Sh. (2012): Artificial Psychology: The Psychology of AI. Conference paper (March 2012).

Daugherty, W. E. (1982): Origin of PsyOps Terminology. In: McLaurin, R. D. (ed.): Military Propaganda. New York: Praeger.

Dupuy, T., Margiotta, F.D., Johnson, C., Motley, J.B. \& Bongard, D.L. (Eds.) (1993): International Military and Defense Encyclopedia. Vol. 5. P-S. Washington, New York: Brassey's (US), Inc.

Farago, L. \& Gittler, Lewis F. (Eds.) (1942): German Psychological Warfare. New York: Putnam.

Friedman, A. H. (2005): Sex and Psychological Operations. Letöltés: 2014.01.30. Web: http://www.psywarrior.com/ sexandprop.html

Galaskó D. (2002): Az amerikai terrortámadások pszichológiai hatásai. Letöltés: 2014.12.01. Web http://www.pszicho logia.hu/cikk/cikk.phtml ?id=115

Holmes, R. (1995): Battle. Dorling Kindersley Ltd., London.

Hovland, C. I. (1954): Effects of the mass media of communication. In Lindzey, G. (Ed.): Handbook of social psychology. Vol. 2. Cambridge, Mass.: AddisonWesley, 1062-1103.

Hovland, C. I., Janis, I. L. \& Kelley, H. H. (1953): Communication and persuasion. New Haven: Yale Univ. Press.

Hovland, C. I. \& Rosenberg, M. J. (Eds.)(1960): Attitude organization and change. New Haven: Yale Univ. Press.

Knezović, Z. és Milković, D. (2007): Pszichológiai manôverek, pszichológiai háború és a háborús hírverés. In: 
Pavlina, Ž. és Komar, Z. (szerk.): Katonapszichológia - Horvát tudományos tapasztalatok (3. kötet). Zrínyi Kiadó, Budapest. 301-331.

Lits G. (2002): Fenyeget-e még a baktériumfegyver veszélye? Hadtudomány; XII. évf. 4. szám; 2002. december; 52-64.

pp.

Maslow, A. H. (1988): Elmélet az emberi motivációról. In: Oláh A. - Pléh Cs. (szerk.): Szöveggyüjtemény az általános és a személyiségpszichológiához. Tankönyvkiadó, Budapest. 373-392.

Mezô F. (2014): PSYOPS - avagy: kalandozás a hadak útján, a pszichológia ösvényein, a történelem útvesztöiben. Kocka Kör, Debrecen.

Mező F. (2019): Interdiszciplináris kapcsolódási lehetőségek a mestersé-ges intelligenciára irányuló cél-, eszköz- és hatásorientált kutatáshoz. Mesterséges intelligencia - interdiszciplináris folyóirat, I. évf. 2019/1. szám. 9-29. doi: 10.35406/MI.2019.1.9

Mező K. (2012): Tehetségmodellek, tehetségdefiníciók. In Mező Ferenc (Szerk.): Tehetségkoordinátorok kézikönyve. K+F Stúdió Kft., Debrecen. 9-22.

Pauchard, J. P. (1989): A lakosság magatartása katasztrófahelyzetben (Rövidített fordítás az Allgemeine Schweizerische Militärzeitschrift, svájci folyóirat 1988. évi 7-8. számából). Honvédelem XL. évfolyam; 1989. 2. szám; 153-158. o.

Pavlina, Ž. és Komar, Z. (szerk.)(2007): Katonapszichológia I-III. Zrínyi Kiadó, Budapest.
Pécsi G. (1989): Kulcs a muzsikáboz: Tankönyvkiadó, Budapest.

Pix G. (2005): A lélektani müveletek jellemzóinek vizsgálata. Doktori (PhD)értekezés. Készült a Zrínyi Miklós nemzetvédelmi Egyetem, Hadtudományi Doktori Iskola keretében. Letöltés: 2014.01.30. Web: http://uninke.hu/downloads/konyvtar/digitgy/ phd/2006/pix_gabor.pdf.

Rózsa S. és Hevesi K. (2006): A pszichológiai mérés történeti gyö-kerei és a mérés problémája a pszichológiában. In Rózsa Sándor, Nagybányai Nagy Oivér és Oláh Attila (szerk.): A pszichológiai mérés alapjai. Bölcsész Konzorcium, Budapest. 7-24. Sherif, M. \& Hovland, C. I. (1961): Social judgement. New Haven: Yale Univ. Press

Spiller, R. J. (1989): A hadviselés emberi dimenziója a xx. Században. (Rövidített fordítás a Military Review 1988. évi 5. számából). Honvédelem XL. évfolyam; 1989. 3. szám; 108-117. o.

Szabó J. (szerk.)(1995): Hadtudományi Lexikon I. kötet. Magyar Hadtudományi Társaság, Budapest.

Terman, L. M. (1925): Mental and physical traits of a thousand gifted children. Stanford University Press, Stanford (California).

Warry, John (1980): A klasszikus világ hadmüvészete. Gemini Kiadó, Budapest.

Zajonc, R. (1984): A kogníció és a szociális kogníció. Történeti áttekintés. In: Hunyady György (szerk.): Szociálpszichológia. Gondolat Kiadó, Budapest. 544-579. 